\title{
ABELARDO CARRILLO Y GARIEL
}

(1898-1976)

\author{
Por Jorge Alberto Manrique
}

El 10 de julio de 1976 murió uno de los estudiosos más conspicuos y serios del arte mexicano: el profesor don Abelardo Carrillo y Gariel, que había nacido en la ciudad de Saltillo, Coahuila, el 20 de mayo de 1898

El Instituto de Investigaciones Estéticas siente como propia la desaparición del profesor Carrillo y Gariel, que aunaba su gran sabiduría y su gran amor a las cosas del arte mexicano con un trabajo perseverante y callado. Aunque don Abelardo nunca fue miembro del Instituto, estuvo ligado a él por su quehacer académico y por la amistad que lo unió a varios de sus miembros. Este Instituto tuvo la satisfacción de publicar algunas de sus obras: la Técnica de pintura de Nueva España (1946) y los Autógrafos de pintores coloniales que conoció dos ediciones (1953 y 1972); en prensa está su estudio Grabados de la colección de la Academia de San Carlos, acerca del cual habiamos firmado un contrato con él poco antes de su muerte, y que desgraciadamente aparecerá póstumo. También existe el proyecto de dar a la prensa otros de los libros que don Abelardo dejó preparados, y de adquirir de sus herederos alguna de la rica documentación que había recopilado cuidadosamente.

Desde 1916, ya en la ciudad de México, ingxesó como alumno a la Academia de San Carlos, la ahora denominada, oficialmente, Escuela Nacional de Artes plásticas de esta Universidad. Muy poco después, a partir de 1919, empezó a escribir artículos de crítica artística en El Heraldo Ilustrado. Esa actividad la continuaría desempeñando por un lapso largo, hasta fines de los años treinta, en esa misma u otras publicaciones, como Excelsior, Jueves de Excelsior, Revista de Revistas, El Universal.

Un viaje a España y otros paises europeos y los Estados Unidos, a partir de 1921 en que terminó sus estudios, le permitió especializarse en técnica de restauración y en historia del arte, así como entrar en contacto con artistas importantes o con jóvenes - principalmente latinoamericanos- que después lo serían. Desde el extranjero continuó escribiendo sus artículos, entre los que destaca, entonces, una entrevista con el arquitecto Gaudi (Excelsior, octubre, 1921). 
En 1926, de vuelta en México, fue nombrado conservador de las Galerías de Pintura de San Carlos -y mucha de su obra posterior revela el amor que cobró a esa colección- y un año después maestro en la misma academia. Más tarde sería secretario de ella, en el tiempo en que la dirigía Diego Rivera. En mayo de 1930 fundó la agrupación "Los dieciocho", que reunía a otros tantos artistas, entre ellos a Francisco Díaz de León, Carlos Alvarado Lang, Ignacio Asúnsolo, Fidias Elizondo, Guillermo Toussaint.

En 1931 era jefe de restauradores en el Departamento de Monumentos Artísticos e Históricos de la Dirección de Monumentos Coloniales. Hacia esa época se advierte un cambio en sus actividades; abandona, de hecho, la práctica artística y aunque conserve amistad no sigue tan estrechamente ligado con los grupos de artistas. Desarrolla en cambio la actividad más estrictamente académica: impartiría cursos en la Escuela Nacional Preparatoria, Universidad Iberoamericana, Instituto de Artes de México y en otras instituciones. En 1945 fue nombrado historiador del Museo Nacional de Historia y en 1949 historiador de la Dirección de Monumentos Coloniales. Pero sobre todo destaca su actividad como investigador, aquella por la que principalmente lo conocimos y por la que ahora nos resulta especialmente lamentable su desaparición. De 1939 es su obra Datos sobre la Academia de San Carlos de Nueva España, y a partir de entonces se sucedería una larga serie de obras, algunas centrales, sobre el arte mexicano del virreinato y del siglo xrx.

Ese fue el hombre de cuya muerte se duelen los historiadores del arte, puesto que sólo ella pudo detener la marcha de sus estudios. Su obra, en cambio, continuará siendo fuente indispensable para quien quiera adentrarse en muchos aspectos de nuestro arte. 
DOI: http://dx.doi.org/10.22201/iie.18703062e.1977.47.1085

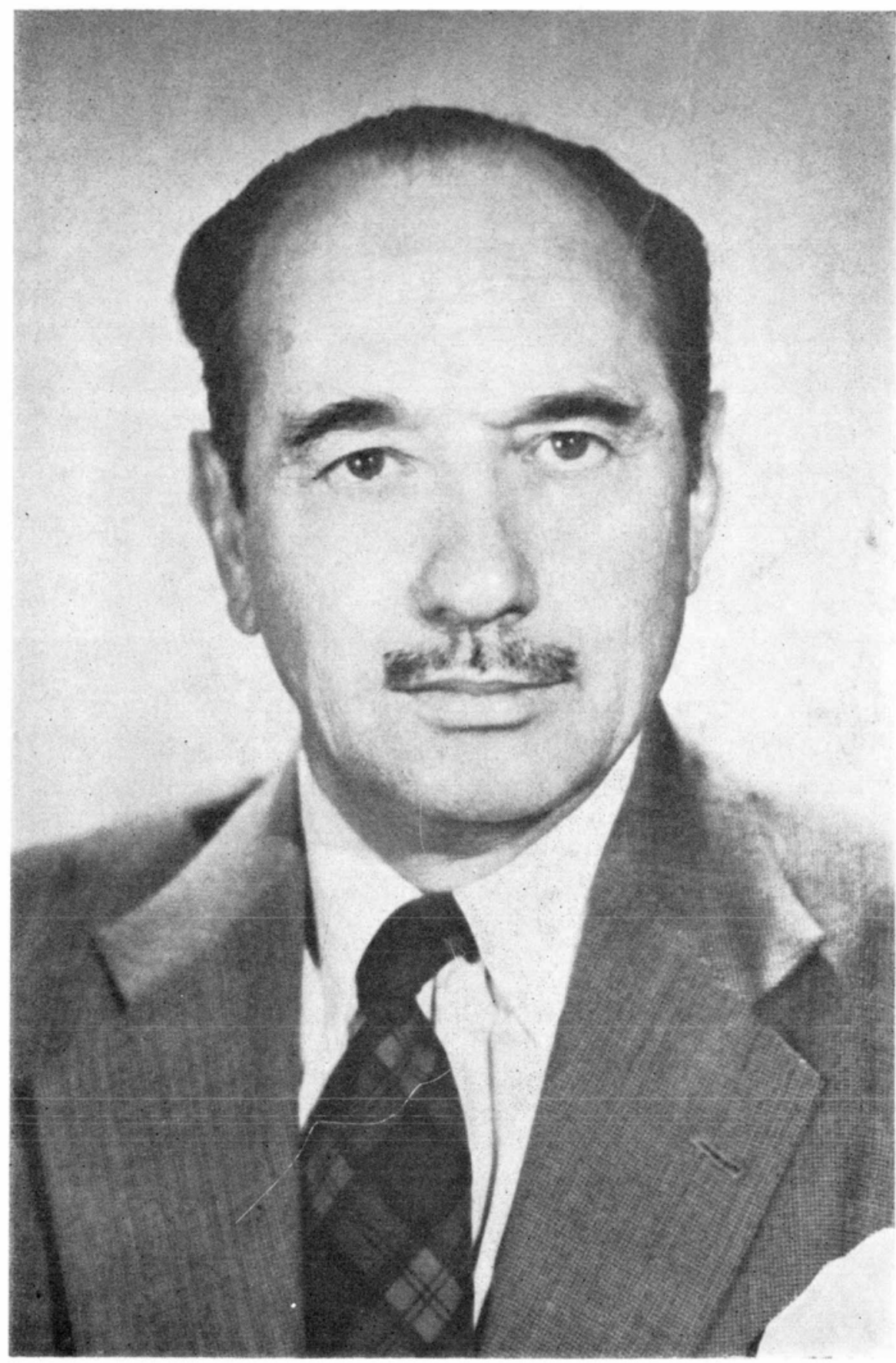

Abelardo Carrillo y Gariel. 